\title{
Information Transfer Technique in Classroom Interaction
}

\author{
ZHAO Ju-qing, MENG Zi-yan \\ Shandong University, Weihai, China
}

\begin{abstract}
Traditional teaching methods have been used in our College English teaching for years and they have contributed a lot to our students' English learning. Yet their disadvantages do exist. In order to compensate for the defects, information transfer technique is introduced into our practical teaching. In the paper its theoretical basis is discussed and it also throws lights on how to select materials and how to design different tasks for information transfer.
\end{abstract}

Keywords: traditional teaching methods, disadvantages, information transfer

\section{Introduction}

College English teaching reform in China has been carried out for more than a decade and communicative approach has been widely used in the language teaching field. Accompanying this approach, the information transfer technique has been introduced to the language teaching class, which can solve some problems with the traditional methods in most TEFL (Teaching English as a Foreign Language) classrooms.

\section{The Disadvantages With the Traditional Teaching Methods}

Traditional teaching methods have existed for more than a century. True, there are some advantages for its existence. But its disadvantages are also obvious. So we have to compensate for them by adopting some new methods. In the traditional TEFL classroom in China, usually the teacher stands on the platform, facing a class of about 50 to 80 students authoritatively, with a textbook in one hand and a piece of chalk in the other. The main focus is on the grammatical rules, the language points, and translation. While the teacher is spending most of the class time imparting language knowledge, the students are busy writing down what the teacher says in order that they can use their notes for examination. The main disadvantage in such a class is that the teacher is too active while the students are too passive. There is a lack of the learner's involvement in the language learning process. And there is little opportunity for the learners to use the language in the classroom. The defects of the traditional teaching methods can be mended by the information transfer technique, which can create opportunities for learners to use the language in class.

\section{Information Transfer}

Littlewood (1981), Nation (1988) and Palmer (1981) claim that information transfer is a communicative activity in which the learner can be actively involved in decoding a piece of information in a purely linguistic or visual symbolic form and motivation to change the information either from a linguistic form into a diagrammatic form or vice versa. The essence of information transfer is that information changes in forms and

ZHAO Ju-qing, associate professor, master, School of Translation and Interpretation, Shandong University. MENG Zi-yan, lecturer, master, School of Translation and Interpretation, Shandong University. 
that the learner, not the teacher, makes the changes, although the teacher provides the learner with the guidance by giving the learner suitable materials and designing activities for the learner. For example, before the teacher reads a weekly school time schedule, he can delete most of the content. The learner is then required to fill the partly blanks sheet when the teacher reads the content out. This is a simple information transfer from listening to writing. In our Integrated Course, learners are always asked to transfer information from reading to writing. And this technique can also be used to train the learner's integrated skills.

The information transfer technique, when properly used in an EFL class, has many advantages over the traditional teaching methods. As far as the relationship between the learner and the teacher is concerned, the learner becomes an active language user and an active participant in various kinds of activities, while the teacher is a guide and consultant. The learner's motivation is to understand and to communicate the meaning in different forms. The diagrammatic framework can provide a context for the learner to predict and comprehend the written or oral information. Littlewood (1981) explains this advantage in great detail. For the language teacher, the technique can also facilitate the classroom management. To sum up, the information transfer activities can lead to a learner-centered class where the learner can learn a foreign language by using it to accomplish different communicative tasks, thus successfully developing learner's communicative ability.

\section{Theoretical Basis for the Information Transfer Technique}

Information transfer has many advantages over the traditional teaching methods because of the fact that it is based on some principles of language learning and acquisition. One of the most noticeable principles from Piaget (1955) is that the better result of language learning can be achieved by doing things with the language. According to this principle, the information transfer technique encourages the learner to be directly involved in communicative activities and to use the target language for communicative purpose. To some degree, learning a language is like learning swimming. Only by plunging into the water can one actually start to learn to swim. Another learning principle from Vygotsky (1962) suggests that learning usually takes place in a social context, especially in a group where some members know more than others. In information transfer activities, there normally exists an information gap between the participants. In order to fill in the gap, the learners are forced to use the target language to make themselves understood or to understand the meaning conveyed by the others. Some language acquisition theories indicate that children acquire their mother-tongue through social interaction. This principle equally applies to adult foreign language acquisition. We can summarize different principles by quoting from Wilkins (1976):

The whole basis of a notion (communicative) approach to language teaching derives from the conviction that what people want to do through language is more important than mastery of the language as unapplied system. The information transfer technique is serving as a bridge that links the linguistic theories with the practical teaching. (Palmer, 1981, pp. 129-33)

\section{Developing Materials for Information Transfer and Designing Information Transfer Tasks}

For most language teachers, what interests them most is the content of the activities rather than the theoretical implication. In this connection, we may as well quote the three questions raised by Nation (1988) as the criteria for an ideal material development.

(1) How will the language items learned today help with tomorrow's language use?

(2) Is the information presented in the activity useful? 
(3) How much control does the learner have over the learning?

Although Nation's main concern is how well the information transfer activities can be used, these three questions also highlight the importance of the material development. From the linguistic point of view, the syntactic structure and vocabulary items are the raw material which the learner can use to produce the output. The materials chosen have direct impact on the quality of the outcome. So the teacher has to bear in mind that the selection of language items should help the learners to build up their linguistic repertoire, on the basis of I+ 1 hypothesis (Krashen, 1982) and the high frequency principle. What's more, the teacher should not only consider the language items in a separate piece of material alone, but take a sequence of materials as a whole. The language items should be well sequenced and systematic. Otherwise, it will be extremely difficult to evaluate the teaching result. From the view point of the communicative value, what Nation emphasizes displays that the teacher should be quite clear as to who he is teaching so that the information in the activity can be valuable to the particular learner. The materials should help to build up the learner's knowledge in a special field. Although this might be a bit demanding for most language teachers who normally received language training before taking up teaching, yet for the efficiency of teaching, the maximum amount of useful knowledge is of vital importance. Therefore, it is widely accepted that the goal of language teaching is not just to impart linguistic knowledge, but the knowledge of the world. The final question leads the teacher to the consideration of different rhetorical acts in materials. Nuttall (1987) holds that by rhetorical acts, we mean that there are different patterns which display the writer's thoughts. The pattern at different levels can be combined into the overall pattern of the whole text. The task for the teacher at this stage is to judge whether there are any typical patterns in the text organization and whether the patterns can be generalized into an information transfer activity over which the learner can gain more control. In fact, Nation's three questions direct the language teacher to the careful selection of materials for information transfer activities in a systematic, objective, and effective way.

Let's have a look at a passage from "College English Writing".

\section{Television}

When the television was invented in 1923, parents had no idea of the harmful effects this celebrated invention would one day have on children. Because of the tremendous amount of time children spent watching $\mathrm{TV}$, they became passive observers. As a result, television has a negative effect on children's learning ability and creativity. Since children spend more time in front of the TV and less time on a good book, their reading abilities have also suffered. Another harmful effect of television is caused by the excessive violence in many popular programs. Consequently, youngsters imitate the aggressive behavior they see on TV. For all these reasons, television has developed from the miracle it once was into the monster it is today.

If we check the paragraph against Nation's three questions, we may have some idea of who the material is suitable for. This paragraph tells us the harmful effects of television on children. The first sentence serves as the topic sentence; it tells us the main idea of the paragraph. Students should bear it in mind that topic sentence is usually placed at the beginning of the paragraph and it tells us the general idea of the paragraph. Namely, if you read the topic sentence carefully, you can grasp the main idea quickly. The second and the third sentence analyze the first harmful effect of television. The fourth sentence analyzes the second harmful effect of television. The fifth and the sixth sentence analyze the third harmful effect of television. The last sentence is a summary. (Students should always remember that usually the last sentence or the last paragraph is the 
conclusion of the paragraph or the conclusion of the essay.) Based on the above analysis, the author comes to the conclusion that television has developed into a monster. The whole paragraph is very well-written and is developed by the way of cause-and-effect. The syntactical and lexical items are suitable for the students at the intermediate-plus level since there are five complex sentences out of seven sentences in the passage. There are only six or seven words which students are not familiar with (tremendous, excessive, violence, consequently, imitate, aggressive). Although the information in the passage may be useful for the people who are interested in, it mainly appeals to the interest of the general public. So the text can be used for the intermediate plus level and general readers.

What Nation suggests in his three questions to us mainly concerns with the principles for material selection or development. As for how the information transfer activities should be carried out, we can probably turn to Littlewood for directions: In the activities, the learners can be given varying amount of help by the table (or framework) which the teacher provides. However, as learners gain independence, the teacher can make this preparatory guidance less detailed. Later, the instruction may be simply to take notes about the main points mentioned in the text. In this way, the teacher can gradually make the learner less dependent on outside help, and more capable of structuring their own listening.

We may note that what Littlewood stresses is that there should be a controlled-half-controlled - almost free process in the information transfer activities. His main focus is on listening. The teacher should be consciously aware of this process and make various tasks for the learners in the activities. This may avoid some of the deficiencies that information transfer activities might have if they are not well designed.

In the listening comprehension or reading comprehension of "television", students can be provided with a task in which the table is used to reveal the pattern of the text organization.

Task:

Use the Information From the Passage to Complete the Table

Television has three harmful effects on children.

1.

2.

3.

Television has developed from the miracle it once was into the monster it is today.

The following three passages are all from "New Horizon College English" Book two. And we can design different information transfer activities according to different passages.

Passage One. (Script) (New Horizon College English Book 2, 2011, p. 18)

Amy: What did you think of the movie, Peter? Did you like it?

Peter: Not really, Amy. It seemed that the director was just trying hard to impress us with strange close-ups and special sound effects, but he forgot to include a good story.

Amy: The movie made you think. It was different from the superficial dialogues you usually see in movies these days.

Peter: But the movie seemed to be too dark and sad. Why does a movie have to be sad to be deep?

Amy: But it is better than some violent movies with nothing but gunfights and exploding cars. I prefer thought-provoking movies.

Peter: Sometimes you don't want to think. You just want light-hearted movies. By the way, did you see 
the new mystery movie shown at the local cinema yesterday?

Amy: Oh, it was so suspenseful. I was on the edge of my seat the whole time.

Peter: I loved it too. The plot was great, and the acting was unbelievable.

Amy: Now we've found something in common. I guess we can watch mysteries together in the future.

\section{Task: Listen to the dialogue and fill in the blanks with what you hear}

Peter did not really like the movie because the was just using strange close-ups and special , but did not include a Amy enjoyed the movie because it made people Peter disagrees, saying a movie

does not have to be to be deep. Amy argues that it is better than some movies. Still, Peter thinks sometimes people don't want to think and just want Finally Peter and Amy found something They both liked the new , so they can watch mysteries together

\section{Passage Two. (Script) (New Horizon College English Book 2, 2011, p. 42)}

A young woman brings home her fiancé to meet her parents. After dinner, her mother tells her father to find out about the young man's plans. The father invites the fiancé to his study for a drink.

"So what are your plans?" the father asks the young man.

"I'm a Bible student," he replies.

"A Bible student? Hmm" the father says. "Good, but what will you do to provide my daughter with a nice house, such as she's accustomed to?"

"I will study," the young man replies, "and God will provide for us."

"And how will you buy her a beautiful engagement ring, such as she deserves?" asks the father.

"I will concentrate on my studies," the young man replies, "and God will provide for us."

"And children?" asks the father. "How will you support children?"

"Don't worry, sir. God will provide," replies the fiancé.

The conversation goes on like this, and each time the father questions him, the young man insists that God will provide. Later the mother asks, "How did it go, honey?" The father answers, "He has no job and no plans, but the good news is he thinks I'm God."

Task: Listen to the passage and answer the questions by complete the statements.

What does the young woman's mother ask the father to find out?

The mother asks the father to find out about

After the young man says "I'm a Bible student", what does the father ask?

He asks, "What will you do to provide my daughter with a , such as she's accustomed to?"

What does the young man say to answer the father's question above?

He says, “ ."

What does the young man say to reply to the father's question "How will you support children?"

He replied, “ . God will provide."

5. What does the father mean when he says "the good news is he thinks I'm God."

In fact he is being humorous. He expects that he will have to play the role of God and provide for in the future.

The three tasks above are controlled exercises. At the half-controlled stage, the learners could be asked to listen to short biography of a famous person and to take notes on the important dates and events for that person. At the almost free stage, the learners could be asked to write their own experiences. The three steps in 
information transfer activities are very important because learning needs habit formation, imitation, and creation.

\section{Conclusion}

True, the information transfer technique cannot solve all the problems in teaching. But the TELF class can be managed more successfully and successful learning can take place if we teachers take the following measures. In the first place, the information transfer technique is to be used in the TEFL classrooms. In the second place, teachers should take into account the language items, the information content and rhetorical acts in the material development. Besides, information transfer activities are carried out in a controlled-half controlled - almost free process. Finally, learners should be actively involved in the communicative activities in class. In the present world, everything is changing, and language teaching is no exception. Language teachers should make efforts to meet the pedagogical needs instead of just adhering to the traditional methods.

\section{References}

Brown, H. D. (1994). Principles of language learning and teaching. Pearson: Hall Regents.

Harmer, J. (1983). The practice of English language teaching. Pearson: Longman.

Krashen, S. D. (1982). Principles and practice in second language acquisition. Oxford: Pergamon Press.

Littlewood, W. T. (1981). Communicative language teaching. Cambridge: Cambridge University Press.

Littlewood, W. T. (1984). Foreign and second language learning. Cambridge: Cambridge University Press.

Nation, P. (1988). Using techniques well: Information transfer. Guidelines, 18, 117-23.

Nuttall, C. (1987). Teaching reading skills in a foreign language. London: Heinemann Educational Books Ltd..

Palmer, D. M. (1981). Information transfer for listening and writing. English Teaching Forum, 20, 129-33.

ZHENG, S. T., \& WANG, D. W. (2011). New Horizon College English, Book 2. Beijing: Foreign Language Teaching and Research Press. 